\title{
Ameryka Łacińska w polityce zagranicznej Brazylii- niedokończony projekt przywództwa regionalnego
}

\author{
Latin America in Brazil's Foreign Policy - \\ an Unfinished Project of Regional Leadership
}

Stowa kluczowe: Brazylia; Ameryka Łacińska; polityka zagraniczna; Ameryka Południowa

Keywords: Brazil, Latin America, Foreign Policy, South America

Abstrakt: Celem artykułu jest omówienie miejsca i roli Ameryki Łacińskiej w polityce zagranicznej Brazylii. Artykuł prowadzi do konkluzji, że poczqwszy od lat 90. XX w., region ten, przez wiele lat marginalizowany, zyskat istotne miejsce w polityce zagranicznej państwa. Budowa wspólnoty południowoamerykańskiej stała się instrumentem umacniania przywództwa regionalnego, aczkolwiek wskutek braku spójnej strategii wobec najbliższego otoczenia, okazała się ona krótkotrwała.

Abstract: The purpose of the article is to discuss the place and role of Latin America in Brazil's foreign policy. The article leads to the conclusion that, starting from the 1990s, Latin America, a region that was marginalized for many years, gained an important place in Brazilian policy. The construction of the South American community has become an instrument of strengthening regional leadership, although due to the lack of a coherent strategy towards the direct neighbourhood, it proved to be short-lived.

* ORCID ID: https://orcid.org/0000-0001-8216-5113, doktor, Katedra Studiów Regionalnych i Globalnych, Wydział Nauk Politycznych i Studiów Międzynarodowych, Uniwersytet Warszawski. Email: aoberda@uw.edu.pl. 


\section{Wprowadzenie}

Brazylia jest graczem aspirującym do odgrywania istotnej roli na płaszczyźnie globalnej. Ważnym elementem tej strategii jest uporządkowanie i rozwój pozytywnych relacji z najbliższym otoczeniem. Realizacja globalnych celów państwa nie byłaby bowiem możliwabezbrazylijskiego zaangażowania w stabilizację oraz integrację regionu, w którymusiłuje zaznaczać swoją rolę przywódczą, dzięki pragmatycznej polityce zagranicznej, jak też poprzez tworzenie wspólnoty południowoamerykańskiej zogniskowanej wokół Brazylii.

Celem artykułu jest analiza miejsca i roli Ameryki Łacińskiej w polityce zagranicznej Brazylii. Przedmiotem badań będzie również tzw. projekt południowoamerykański, stanowiący podstawę budowania brazylijskiej strefy wpływów w regionie. Zagadnienie to jest interesujące z uwagi na przetasowania polityczne i ideologiczne w obszarze latynoamerykańskim, wieńczące koniec tzw. lewicowego zwrotu w regionie, w tym ukierunkowanie brazylijskiej polityki zagranicznej przez obecną administrację na sojusze pozaregionalne.

Artykuł jest próbą odpowiedzi na dwa główne pytania badawcze: czy Brazylia posiada spójną i konsekwentną politykę wobec najbliższego otoczenia oraz jaką rolę pełni Ameryka Południowa w polityce zagranicznej państwa?

Odpowiedzi pozwolą na weryfikację przyjętej hipotezy, iż Brazylia, pomimo okresów intensywnej współpracy z państwami latynoamerykańskimi, i posiadanego potencjału politycznego oraz ekonomicznego, nie jest w stanie pełnić długofalowo roli regionalnego lidera. Rzeczywiste możliwości Brazylii w tym względzie stawia pod znakiem zapytania m.in. kryzys idei wspólnoty południowoamerykańskiej, która stanowiła najbardziej zaawansowany przykład urzeczywistniania przywództwa brazylijskiego.

Teoretycznym narzędziem zastosowanym do analizy powyższej kwestii jest metoda indukcyjna, która pozwoliła na sformułowanie prawidłowości i uogólnień dotyczących brazylijskiego zaangażowania w regionie.

W pierwszej części artykułu przedstawiona została ewolucja latynoamerykańskiej polityki Brazylii w ujęciu historycznym, z zaznaczeniem głównych etapów umacniania pozycji regionalnej państwa. W kolejnym fragmencie omówiono ideę wyodrębnieniawspólnoty południowoame-

rykańskiej jako głównego punktu odniesienia polityki brazylijskiej. Następnie przedstawione zostały przykłady zaangażowania państwa w najbliższym otoczeniu, wraz z głównymi instrumentami politycznego 
i gospodarczego oddziaływania. W podsumowaniu zaś zostaną zawarte wnioski.

\section{Ewolucja latynoamerykańskiej polityki Brazylii}

Odkryta w 1500 r. przez Pedro Álvaresa Cabrala Brazylia, niemal od początku swej państwowości podążała odmienną drogą niż otaczające ją państwa hiszpańskojęzyczne. Pomimo wspólnych doświadczeń kolonialnych Brazylia, jedyny kraj portugalskojęzyczny w Ameryce Południowej, cesarstwo o gospodarce opartej w dużej mierze na pracy niewolników, wyróżniała się na tle latynoamerykańskich sąsiadów ${ }^{1}$. W czasie kiedy przez kolonie hiszpańskie na początku XIX w. przetaczały się krwawe rewolucje niepodległościowe, prowadzące do powstania pierwszych republik na kontynencie, Brazylia nie tylko nie pogrążyła się w zawierusze powstańczej, ale jako jedyne państwo regionu obrała system monarchiczny, co zapewniło jej względną stabilizację. Obalenie cesarstwa w 1889 r. również odbyło się bez większego przelewu krwi, a José Maria da Silva Paranhos Jr. (1845-1912), baron Rio Branco, architekt brazylijskiej dyplomacji, doprowadził do pokojowego potwierdzenia granic ze wszystkimi sąsiadami, kładąc solidne podwaliny pod politykę zbliżenia z krajami ościennymi, izapewniając państwu swobodę działania w regionie, który uznawał za potencjalny obszar wpływów.

Zarówno w okresie kolonialnym, jak i w trakcie trwania cesarstwa, Brazylia zorientowana była przede wszystkim na Europę, a od końca XIX w. również na Stany Zjednoczone. Państwa latynoamerykańskie nie stanowiły priorytetowego kierunku rozwoju brazylijskiej polityki zagranicznej. Co więcej, przez długi czas ani państwa hiszpańskojęzyczne, ani nawet brazylijscy intelektualiści, nie postrzegali Brazylii jako części Ameryki Łacińskiej. Dopiero w okresie zimnej wojny, pod dużym wpływem StanówZjednoczonych, stopniowozaczęto podkreślać latynoamerykańską tożsamość państwa ${ }^{2}$. Jednocześnie w podejściu Brazylii do najbliższego otoczenia można dostrzec swoistą dychotomię. Z jednej strony izolowano się od sąsiadów, czy to marginalizując ich rolę jako potencjalnych partnerów, czy też obawiając się okrążenia przez państwa hiszpańskojęzyczne.

${ }^{1}$ J.Briceño-Ruiz, A. RivarolaPuntigliano, BrazilandLatin America. Between the separation and integration paths, Rowman\&Littlefield, Lanham 2017.

${ }^{2}$ L. Bethell, Brazil and „Latin America”, «Journal of Latin American Studies» August 2010, vol. 42, nr 3, s. 457-485. 
$\mathrm{Z}$ drugiej jednakże, snuto marzenia o podporządkowaniu sobie regionu i urzeczywistnieniu głęboko zakorzenionego w świadomości politycznej Brazylijczyków przekonania o swoistej wyższości nad państwami latynoamerykańskimi oraz predestynacji do odgrywania przywódczej roli w regionie (grandeza brazileira) ${ }^{3}$.

Na politykę regionalną Brazylii istotny wpływ wywarł również „niepisany sojusz" (aliança não escrita) z USA, który w dużej mierze warunkował stosunki państwa z najbliższym otoczeniem. W praktyce dokonano nieoficjalnego podziału wpływów w zachodniej hemisferze. Stany Zjednoczone, umacniające strefę oddziaływania w Ameryce Środkowej i w basenie Morza Karaibskiego, nie ingerowały bowiem zbytnio w kwestie południowoamerykańskie, dając Brazylii relatywną autonomięi ciche przyzwolenie do odgrywania przywódczej roli w Ameryce Południowej.

PoII wojnieświatowej polityka Brazylii wobec AmerykiŁacińskiejewoluowała od ograniczonych relacji z sąsiadami podczas rządów wojskowych (1964-1985), przez chwilowe zbliżenie w ramach Niezależnej Polityki Zagranicznej (1961-1964), aż po stopniowe ożywienie kontaktów wraz z początkiem demokratyzacji. Począwszy od lat 70 . XX wieku brazylijska polityka zagraniczna zaczęła być traktowana jako istotny instrument rozwoju gospodarczego państwa, a w relacjach z Ameryką Łacińską dostrzec można proces upodmiotowienia Ameryki Południowej. Polityka „odpowiedzialnego pragmatyzmu" (pragmatismo responsável), która pojawiła się w kontekście kryzysu naftowego i narastających spięć w relacjach z USA, zaczęła akcentować przynależność Brazylii do grona państw Trzeciego Świata, w tym do regionu latynoamerykańskiego. Wraz z upadkiem rządów wojskowych i demokratyzacją państwa, konsolidacja tożsamości latynoamerykańskiej Brazylii znalazła odzwierciedlenie w konstytucji z 1988 r., gdzie w art. 4 zapisano, iż ,Federacyjna Republika Brazylii dąży do integracji gospodarczej, politycznej, społecznej i kulturowej ludów Ameryki Łacińskiej, w celu utworzenia latynoamerykańskiej wspólnoty narodów"4.

Od lat 90. XX w. polityka Brazylii wobec państw Ameryki Łacińskiej tworzona była w oparciu o trzy główne filary: demokrację, integrację oraz wykorzystanie zdobyczy globalizacji dla umocnienia swojej pozycji międzynarodowej ${ }^{5}$. Stały się one głównymi elementami strategii kolej-

${ }^{3}$ L.C. Villafañe, G. Santos, A América do Sul no discurso diplomático brasileiro, «Revista Brasileira de Política Internacional» julhio-dezembro 2005, vol. 48, nr 2, s. 185-204.

${ }^{4}$ Konstytucja Federacyjnej Republiki Brazylii z dnia 5 października 1988 r.wg stanu prawnego na 1 lipca 2004 r., Warszawa 2004.

5 C. Brigagão, Relaçôes internacionais com os Estado Unidos e a América do Sul, «Relaçôes Internacionais» março 2011, nr 29, s. 83. 
nych rządów, zarówno tzw. ,autonomii przez integrację” (autonomia pela integração) Fernando Henrique Cardoso (1995-2002), jak i ,autonomii przezzróżnicowanie" (autonomia pela diversificação) Luiza Inacio Lula da Silva (2003-2010), które zastąpiły tradycyjne podejście izolacjonistyczne w polityce regionalnej Brazylii, określane jako,,autonomia przez dystans” (autonomia pela distância). W ich ramach skoncentrowano się na budowaniu i zacieśnianiu sojuszy politycznych z sąsiadami oraz współpracy gospodarczej, która w dużej mierze przyczyniła się do intensywnego rozwoju ekonomicznego państwa na przełomie XX i XXI w. i umocnienia wpływów w regionie Ameryki Południowej.

Podejście takie stanowiło swoiste novum w relacjach z obszarem gdyż, jak pisze J. Spyra, „,do połowy lat dziewięćdziesiątych polityka Brazylii wobec Ameryki Łacińskiej była funkcją jej koncepcji modernizacji państwa"6, umiejscawiając ją przede wszystkim na płaszczyźnie ekonomicznej. Polityka Brazylii wobec państw latynoamerykańskich w dużej mierze warunkowana była bowiem czynnikami wewnętrznymi, takimi jak kryzys zadłużeniowy, proces konsolidacji rządów demokratycznych, czy też potrzeba aktywizacji brazylijskiego sektora produkcji. Stopniowo jednak, poprawę relacji z państwami sąsiednimi zaczęto wpisywać w długofalową strategię wzmocnienia międzynarodowej pozycji państwa, bazującą na równowadze pomiędzy integracją, bezpieczeństwem regionalnym, demokratyzacją i rozwojem infrastruktury.

Ewolucję latynoamerykańskiej polityki Brazylii można, za Susanne Gratius i Miriam Gomes Saraiva, przedstawić w formie kręgów brazylijskiego zaangażowania w regionie. Pozwalają one spojrzeć na politykę Brazylii w perspektywie długofalowego umacniania pozycji w regionie począwszy od ustabilizowania najbliższego sąsiedztwa, przez tworzenie instytucji subregionalnych, do konstrukcji przestrzeni południowoamerykańskiej z Brazylią w centrum.

Pierwszym etapem, który umożliwił zbliżenie z państwami Ameryki Łacińskiej i pogłębienie procesów integracji regionalnej, stałosię unormowanie relacji z Argentyną, tradycyjnym rywalem Brazylii w wyścigu o pełnienie roli mocarstwa regionalnego. Działania w tym kierunku przedsięwzięto pod koniec lat 70., a zintensyfikowały się one wraz z rozpoczęciem procesu demokratyzacji w Ameryce Łacińskiej. W efekcie w 1985 r. podpisano deklarację o promowaniu integracji gospodarczej między sygnatariuszami.

6 J. Spyra, Mocarstwowe aspiracje Brazylii w kontekście regionalnym, [w:] M.F. Gawrycki (red.), Brazylia jako mocarstwo wschodzqce, Warszawa 2013, s. 159. 
Wykres 1. Koncentryczne kręgi brazylijskiego zaangażowania w regionie

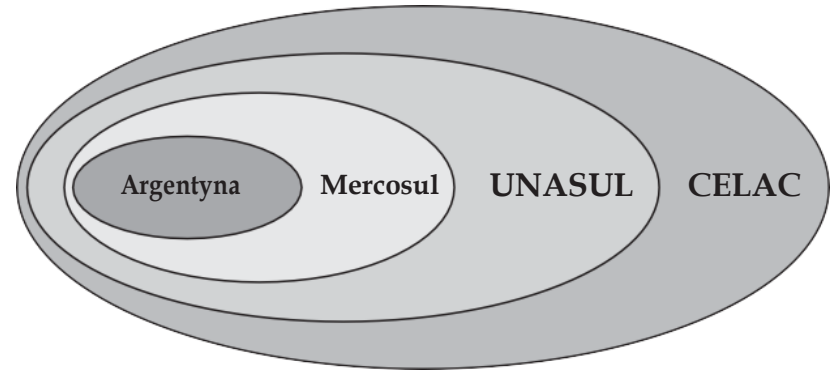

Źródło: opracowanie własne na podstawie S. Gratius, M. Gomes Saraiva, Continental regionalism: Brasil's prominent role in the Americas, CEPS Working Documents, February 2013, nr 374.

Wydarzenia te przygotowały podatny grunt pod powołanie do życia w 1991 r. na mocy traktatu z Asunción Wspólnego Rynku Południa (Mercado Comum do Sul, Mercosul). Stał się on kamieniem węgielnym polityki latynoamerykańskiej Brazylii. Z perspektywy ekonomicznej postrzegany był jako pierwszy krok do ustanowienia unii celnej zgodnej ze strategią rozwojową państwa, mający na celu zwiększenie obrotów handlowych z regionem i przyciągnięcie inwestycji zagranicznych. Pod kątem politycznym z kolei, traktowany był jako mechanizm wzmacniający brazylijską pozycję w relacjach międzyamerykańskich iprocesach integracyjnych regionu, a przez to swoisty wektor konsolidacji pozycji przywódczej $\mathrm{w}$ regionie.

Kolejnym etapem aktywności regionalnej Brazylii stało się dążenie do urzeczywistnienia idei wspólnej przestrzeni południowoamerykańskiej (sulamericanidade). Pierwszym jej przejawem była inicjatywa Brazylii z 1993 r. utworzenia Południowoamerykańskiej Strefy Wolnego Handlu (Área de Livre Comércio Sul Americana, ALCSA) na bazie Mercosulu, która miała być odpowiedzią na lansowaną przez USA Północnoamerykańską Strefę Wolnego Handlu (North American Free Trade Area, NAFTA). Jej instytucjonalizacja nastąpiła w XXI w. poprzez powołanie do życia Unii Narodów Południowoamerykańskich (União de Nações SulAmericanas, UNASUL), która wraz z Mercosulem stała się platformą regionalnej polityki dobrego sąsiedztwa Brazylii.

Stopniowo Ameryka Południowa zaczęła być postrzegana również jako element projekcji globalnej Brazylii. Prowadzić do tego miało m.in. członkostwo we Wspólnocie Państw Ameryki Łacińskiej i Karaibów (Comunidade de Estados Latino-Americanos e Caribenhos, CELAC), znacznie wykraczające poza obszar południowoamerykański. Silna pozy- 
cja $\mathrm{w}$ regionie traktowana była bowiem jako punkt wyjścia do wzmacniania szeroko rozumianej współpracy państw Południa, która to z kolei miała prowadzić do poprawy globalnej pozycji Brazylii.

\section{Ameryka Łacińska czy Ameryka Południowa?}

Od co najmniej lat 90. XX w. można dostrzec w polityce Brazylii pragmatyczne dążenia do konsolidacji południowoamerykańskiej przestrzeni geostrategicznej oraz oparcia na niej tożsamości międzynarodowej państwa ${ }^{7}$. Koncentracja na Ameryce Południowej miała istotne znaczenie dla koncepcji brazylijskiego przywództwa regionalnego. Przede wszystkim zarysowywała konkretny obszar oddziaływania w przeciwieństwie do niespójnego, trudnego do zdefiniowana politycznie pojęcia Ameryki Łacińskiej ${ }^{8}$. Pozwalała również wykluczyć ze strefy wpływów potencjalnych rywali, jak Meksyk, oraz zapewniała autonomię i równoważenie wpływów Waszyngtonu w zachodniej hemisferze, zwłaszcza w kontekście powołania do życia NAFTA i promowanej przez Stany Zjednoczone idei Strefy Wolnego Handlu Obu Ameryk (Free Trade Area of the Americas, FTAA). Warto wspomnieć, iż budowana na bazie Ameryki Południowej wspólnota wartości pozwalała Brazylii wzmocnić, wielokrotnie poddawaną w wątpliwość przezpaństwa sąsiednie, tożsamość regionalną państwa. Jednocześnie, kryzysy polityczne w państwach sąsiednich oraz militaryzacja działań Stanów Zjednoczonych w Amazonii wymusiły na Brazylii odejście od rygorystycznej interpretacji zasady nieinterwencji izaangażowanie się w stabilizację południowoamerykańskiegootoczenia, a rosnąca autonomia Argentyny w ramach Mercosulu zmobilizowała do stworzenia silnej przeciwwagi politycznej i gospodarczej oraz intensyfikacji procesów integracyjnych ${ }^{9}$.

Koncepcja Ameryki Południowej jako obszaru szczególnej aktywności Brazylii również ewoluowała. O ile początkowo odnosiła się ona przede wszystkim do państw Cono Sur, o tyle w latach kolejnych została roz-

${ }^{7}$ L. Freitas Couto, O horizonte regional do Brasil e a construção da América do Sul, «Revista Brasileira de Política Internacional» 2007, vol. 50, nr 1, s. 163.

8 P.R.de Almeida, Lula's foreign policy: regional and global strategies, [w:] J.L.Love, W.Baer (red.), Brazil under Lula: economy, politics, and society under the rock-president, New York 2009, s. 177.

${ }^{9}$ S. Adins Vanbiervliet, El liderazgo brasileño en Sudamérica: una aspiración de corta duración, «Revista Andina de Estudios Políticos» 2014, vol. IV, nr 2, s. 58. 
szerzona o państwa takie jak Gujana czy Surinam ${ }^{10}$. Obecnie Brazylia coraz odważniej zaznacza swoją obecność także na obszarze Ameryki Środkoweji Karaibów, wkraczając tym samym do strefy wpływów Stanów Zjednoczonych, przy wykorzystaniu m.in. mechanizmu dyplomacji etanolowej i sojuszy z państwami uzależnionymi od dostaw taniego paliwa.

Początek urzeczywistniania brazylijskiego projektu Ameryki Południowej jako odrębnego systemu geopolitycznego i wprowadzenia go na scenę międzynarodową pod własnym przywództwem przyniósł szczyt państw południowoamerykańskich w 2000r.w Brasilii. Jak stwierdziłbyły brazylijski prezydent F.H. Cardoso, był to ,,moment reafirmacji tożsamości Ameryki Łacińskiejjakoregionu”, w którym,,porozumienie o wolnym handlu między Mercosulem a Wspólnotą Andyjską stało się kręgosłupem Ameryki Południowej pojmowanej jako rozszerzona przestrzeń ekonomiczna"11. W pewnym sensie przypieczętowano wówczas zgodę na konsensualne przywództwo Brazylii w regionie, oparte na hegemonii kooperatywnej, czyli koordynacji współpracy, konsultacji i dialogu ${ }^{12}$.

Momentem przełomowym dla realizacji idei wspólnoty południowoamerykańskiej zbudowanej wokół Brazylii były rządy L.I. Lula da Silva. Strategia tworzenia spójnej przestrzeni Ameryki Południowej opierała się przede wszystkim na soft power, wzmacnianiu współpracy multilateralnej oraz rozbudowaniu sieci powiązań instytucjonalnych w regionie, nadając priorytet współpracy technicznej i finansowej oraz wpisując się w politykę współpracy państw Południa. Agenda południowoamerykańskauległa wówczas istotnemu upolitycznieniu, co widać m.in. w pogłębianiu relacji z państwami ideologicznie zbieżnymi. Jednocześnie Brazylia, czołowy przedstawiciel „Różowej Fali”'13, dążyła do zrównoważenia relacji handlowych w integracji regionu rozwojem infrastruktury, walką z narkotykami, koordynacją współpracy politycznej, czyli integracją wielowymiarową ${ }^{14}$. Jej

${ }^{10}$ C.G. Poggio Teixeira, Brazil and the institutionalization of South America: from hemispheric estrangement to cooperative hegemony, «Revista Brasileira de Política Internacional» 2011, vol. 2, nr 54, s. 204.

11 Tamże, s. 203.

12 S.W. Burges, Consensual hegemony: theorizing Brazilian foreign policy after the Cold War, «International Relations» 2008, vol. 22, nr 1, s. 65-84.

13 Terminem „Różowa Fala” określano rządy lewicowe, które doszły do władzy w państwach Ameryki Łacińskiej na przełomie XX i XXI w. Charakteryzowała je m.in. krytyka neoliberalizmu, niechęć wobec dominującej pozycji USA w regionie, poparcie dla demokracji przedstawicielskiej czy walka z nierównościami rozwojowymi.

${ }^{14}$ B. Sorj, S. Fausto, El papel de Brasilen América del Sur: estrategias y percepciones mutuas, [w:] B. Sorj, S. Fausto (red.), Brasil y América del Sur: miradas cruzadas, Buenos Aires 2011, s. 17. 
ukoronowaniem stało się utworzenie w 2008 r. UNASUL. Niski stopień instytucjonalizacji Unii umożliwiał Brazylii zachowanie dużej autonomii w polityce latynoamerykańskiej, a brak konkretnych zobowiązań ułatwiał kształtowanie strategii gospodarczej bez ograniczeń typowych np. dla Mercosulu i pozwolił na przejęcie inicjatywy w procesach integracyjnych, dając bezprecedensową możliwość bezpośredniego kształtowania krajobrazu politycznego Ameryki Południowej.

Począwszy jednakże od drugiej kadencji L.I. Luli da Silvy (2007-2014) można zauważyć stopniowe ostudzenie entuzjazmu dotyczącego współpracy z państwami sąsiednimi. Na płaszczyźnie wewnętrznej uwidoczniły się poniekąd tradycyjne przeszkody hamujące integrację regionalną, w tym narastający sceptycyzm brazylijskiej opinii publicznej wobec głębszej integracji z sąsiadami, kryzys zaufania wobec władzy uwikłanej w kolejne afery korupcyjne, czy brak spójnej polityki wobec regionu. Wśród najczęściej przytaczanych powodów przejścia do biernej polityki regionalnej wymienia się również brak zainteresowania kolejnych rządów polityką zagraniczną lub typową dla Brazylii tendencją do pojawiania się po okresach aktywizacji międzynarodowej czynników hamujących, określanych przez A. Hurrella i G.L. Gardiniego ,niejasnościami” (ambiguities) oraz ,strategicznym chaosem" (strategic confusion) ${ }^{15}$. Przeniesiono wówczas nacisk w polityce południowoamerykańskiej z multilateralizmu na selektywny bilateralizm, równoważąc priorytetową pozycję Ameryki Południowej innymi kierunkami zaangażowania międzynarodowego państwa.

Dilma Rousseff (2011-2016) oraz Michel Temer (2016-2018) deklarowali wprawdzie kontynuację kierunku regionalnej polityki poprzednika, ale wskutek pogłębiającego się kryzysu politycznego oraz pierwszych oznak wyczerpywania się społeczno-gospodarczego modelu rozwoju promowanegoprzez, Różową Falę”, Brazylia zaczęła stopniowotracić impet w regionie, o czym świadczyła m.in. bierna postawa wobec procesu pokojowego w Kolumbii czy kryzysu w Wenezueli. Istotnym wyzwaniem stało się również powstanie Sojuszu Pacyfiku (Alianza del Pacífico, AP), który wzmocnił tradycyjne podziały Ameryki Południowej, stając się atrakcyjną alternatywą dla państw regionu niezadowolonych z apatii Mercosulu, ambicji przywódczych Brazylii, czy też protekcjonizmu Argentyny.

15 Więcej zob. F.Zanini, Foreign policy in Brazil: a neglected debate, «Harvard International Review» October 2014; A. Hurrell, Lula's Brazil: a rising power, but going where?, «Current History» 2008, vol. 107, nr 706; G.L. Gardini, Brazil:what rise of what power?, «Bulletin of Latin American Research» 2015, vol. 35, nr 1. 


\section{Polityczne i gospodarcze zaangażowanie Brazylii w regionie}

Niektórzy badacze twierdzą, że subregion południowoamerykański jest obszarem, w którym dominuje jednobiegunowy układ sił, z Brazylią jako głównym punktem odniesienia ${ }^{16}$. Dążenie do potwierdzenia przywódczej roli państwa postrzegane jest jako element równoważący obce wpływy w regionie i determinujący możliwości oddziaływania międzynarodowego państwa. Stąd m.in. wsparcie Brazylii dla procesów integracji regionalnej, czy też wprowadzenie do Wspólnego Rynku Południa tzw. klauzuli demokratycznej, pozwalającej na nałożenie sankcji na państwa członkowskie nie przestrzegające reguł demokracji.

Pretendując do miana politycznego lidera, Brazylia stopniowo przejęła także inicjatywę $w$ organizacji nowej przestrzeni bezpieczeństwa m.in. poprzez powołanie do życia Południowoamerykańskiej Rady Bezpieczeństwa (Conselho de Defensa Sul-Americano, CDSA) ${ }^{17}$ oraz występuje w roli regionalnego mediatora, angażując się w rozwiązywanie środkami pokojowymi wszelkich sporów i kontrowersji mogących zdestabilizować najbliższe otoczenie. Kompromisem pomiędzy zasadą nieinterwencji, stanowiącą istotne spoiwo systemu międzyamerykańskiego, a polityczną aktywnością Brazylii stała się przyjęta w polityce zagranicznej zasada não intervenção i não indiferença. Ta swoista reinterpretacja zasady nieinterwencji służyła jako uzasadnienie brazylijskiego zaangażowania w rozwiązywanie kryzysów politycznych i społecznych w innych państwach, pozwalając na stosowanie szeroko rozumianej mediacji oraz pomocy w czasie kryzysów humanitarnych ${ }^{18}$.

Brazylijska strategia umocnienia wpływów politycznych w Ameryce Południowej majednak liczne rysy i pęknięcia. Percepcja Brazylii w regionie jest bowiem co najmniej ambiwalentna ${ }^{19}$, a dążenie do osiągnięcia statusu lidera $\mathrm{w}$ regionie, nie zawsze spotyka się z poparciem państw

${ }^{16}$ L.L. Schenoni, The Brazilian rise and the elusive South American balance, «GIGA Research Programme: Power, Norms and Governance in International Relations Working Paper» March 2015, Nr 269 https://www.giga-hamburg.de/en/system/files/publications/ wp269_schenoni.pdf (14.08.2019).

${ }^{17}$ A.W.M. Teixeira Júnior, Explaining defense cooperation with process-tracing: the Brazilian proposal for the creation of UNASUR South American Defense Council, «Revista Brasileira de Política Internacional» 2017, vol. 60, nr 2, s. 4.

${ }^{18}$ K. Ekström, L.M. Alles, Brazilian foreign policy under Lula: from non-intervention to nonindifference, «Political Perspectives» 2012, vol. 6 (2), s. 9-29.

${ }^{19}$ A. Malamud, A leader without followers? The growing divergence between the regional and global performance of Brazilian foreign policy, «Latin American Politics and Society» 2011, vol. 53, nr 3. 
latynoamerykańskich, co dostrzec można chociażby w staraniach o uzyskanie stałego miejsca w Radzie Bezpieczeństwa ONZ.

Państwa południowoamerykańskie chętnie korzystają z brazylijskiego wsparcia technicznego, pomocy gospodarczej i doradztwa politycznego, ale w praktyce obawiają się imperializmu brazylijskiego, krytykując Brazylię za tendencje hegemoniczne, oraz unikanie pełnej odpowiedzialności związanej z przywództwem w regionie. Zarzuca się jej, że jest liderem niechętnie ponoszącym koszty przywództwa regionalnego, wybiórczo angażującym się w rozwiązywanie problemów regionalnych, gdzie kieruje się przede wszystkim własnymi interesami. Brazylia unika zatem w oficjalnej retoryce nawiązywania do przywództwa regionalnego, preferując pojęcie opartej na współpracy hegemonii konsensualnej.

Jednocześnie, jako największa gospodarka regionu pozostaje istotnym katalizatorem rozwoju ekonomicznego w Ameryce Południowej, zarówno poprzez przewagę gospodarczą jak i możliwości finansowego oddziaływania. Jednym z pierwszych elementów strategii wzmocnienia pozycji Brazylii w Ameryce Południowej, pojmowanym jako mechanizm organizowania przestrzeni południowoamerykańskiej a także ograniczania ekspansji gospodarczej USA w regionie, stał się Mercosul. Pozwolił on Brasilii przejąć inicjatywę w integracji regionalnej, co widać również w idei ALCSA. W założeniu projekt ten miał być komplementarny wobec Mercosulu, zapewniając kontynentalny przyczółek dla ekspansji gospodarczej Brazylii w obliczu ekonomicznej ofensywy regionalnej USA. Mimo szeroko zarysowanych ram członkostwa, nie obejmował m.in. państw karaibskich, zapowiadając preferencje geograficzne brazylijskiego zaangażowania, czyli Amerykę Południową.

L.I. Lula da Silva dążył do intensyfikacji kontaktów handlowych, przekształcając Brazylię stopniowo w głównego płatnika regionu. Jednocześnie w kontaktach z państwami południowoamerykańskimi nadano priorytet współpracy technicznej i finansowej. W jej ramach rozwinięto szeroką działalność na rzecz rozwoju infrastruktury w dziedzinie transportu, komunikacji i energii poprzez m.in. Inicjatywę na rzecz Integracji Infrastruktury Regionalnej Ameryki Południowej (Iniciativa para la Integración de la Infraestructura Regional Suramericana, IIRSA). Instrumentem wykorzystywanym przez Brazylię w tej kwestii jest także Narodowy Bank Rozwoju (Banco Nacional de Desenvolvimiento, BNDES), który finansuje projekty infrastrukturalne, m.in. w Boliwii, Peru czy Argentynie. Pragmatyczna polityka wobec sąsiadów oparta na wsparciu finansowym widoczna była m.in. podczas kryzysu gospodarczego w Argentynie, nacjonalizacji zasobów ropy i gazu w Boliwii, czy też pomocy technicznej 
udzielanej państwom zależnym od dostaw energii w ramach tzw. dyplomacji etanolowej. Z inicjatywy Brazylii powołano również do życia Fundusz Zbieżności Strukturalnej (Fundo para a Convergência Estrutural do Mercosul, FOCEM), mający na celu usuwanie nierówności pomiędzy państwami członkowskimi.

Ekonomiczne podstawy brazylijskiej strefy wpływów budowanej m.in. poprzez hojną politykę wsparcia gospodarczego są jednak zawodne. Osłabienie gospodarki Brazylii w ostatnich latach wyhamowało zaangażowanie państwa w najbliższym otoczeniu, co przełożyło się na słabsze poparcie regionalne dla brazylijskich ambicji przywódczych. Wprawdzie Brazylia pozostaje największą gospodarką południowoamerykańską, musi się jednakże liczyć zutratą mianajedynegorynku wschodzącego w regionie na rzecz Meksyku oraz rosnącą konkurencją ze strony dynamicznie rozwijającego się AP, który pozostawia w tyle pogrążony w stagnacji Mercosul20.

\section{Konkluzje}

Głęboko zakorzenione w brazylijskiej polityce przekonanie o predestynacji do odgrywania istotnej roli na płaszczyźnie globalnej zazwyczaj przypomina o sobie pomiędzy kolejnymi kryzysami ekonomicznymi i destabilizacjami politycznymi, które sprawiają, że jest ono głównie pobożnym życzeniem. Krokiem do tego celu miało być umocnienie wpływów w najbliższym otoczeniu i osiągnięcie pozycji regionalnego lidera. Z racji głębokich uprzedzeń sąsiadów wobec jakiejkolwiek formy dominacji i niechęci do wszelkich form hegemonii, aspiracje te nie były nigdy wyrażone explicite i nazywane są kompromisowo przywództwem konsensualnym. Przemiany polityczne i reformy gospodarcze lat 90 . przygotowały podatny grunt dla stopniowego urzeczywistniania brazylijskiej strefy wpływów za rządów lewicowych, pragmatycznie ograniczonej do Ameryki Południowej. Tzw. projekt południowoamerykański, traktowany jako krok na drodze do zwiększenia globalnej roli państwa, był wówczas

20 Brak konsekwentnej polityki gospodarczej Brazylii objawiający się okresami intensywnego wzrostu ekonomicznego i następującą po nich stagnacją nazywany bywa „klątwą kurzego lotu". A.G. Valladão, Emergent Brazil and the curse of the "hen's flight”, [w:] M. Emerson, R. Flores (red.), Enhancing the Brazil-EU strategic partnership from the bilateral to the global, Brussels 2013. Zob. też K.E. Lehmann, Can Brazillead? The breakdown of Brazilian foreign policy and what it means for the region, «Rising Powers Quaterly» 2017, vol. 2 , nr 2 . 
rzeczywiście bliski realizacji. Polityczna i gospodarcza pozycja Brazylii w regionie nigdy nie była silniejsza, co przejawiało się m.in. w przejęciu inicjatyw w procesach integracji regionu, roli gwaranta bezpieczeństwa, czy motoru ekonomicznego rozwoju. Pomimo rosnącej pozycji, Brazylia nie mogła jednak liczyć w pełni na poparcie regionalnych sojuszników co znacznie osłabiło jej mandat lidera.

Odpowiadając na postawione pytania badawcze należy zatem stwierdzić, iż przywództwo regionalne Brazylii ma niezwykle kruche podstawy, na co wpływa głównie brak spójnej strategii zaangażowania w najbliższym otoczeniu oraz konsensusu politycznego co do roli jaką ma odgrywać Ameryka Łacińska w polityce państwa. Po okresie intensyfikacji polityki latynoamerykańskiej, pomimo utrzymywania u schyłku rządów lewicowych w oficjalnej retoryce haseł zbliżenia z regionem, w praktyce utracił on na znaczeniu, a w miejsce multilateralizmu - jako głównego instrumentu polityki regionalnej, skoncentrowano się na stosunkach dwustronnych z państwami latynoamerykańskimi. Jednocześnie podejście ideologiczne stopniowo zastąpił typowy dla brazylijskiej polityki zagranicznej pragmatyzm.

Impeachment D. Rousseff w 2016 r. przyniósł początek końca ambitnego projektu południowoamerykańskiego w polityce Brazylii. Uwidoczniły się również tradycyjne wyzwania blokujące procesy integracyjne i stawiające pod znakiem zapytania budowanie brazylijskiej strefy wpływów w regionie. Przykładem narastającego kryzysu i odwrotem od idei umacniania przywództwa w Ameryce Południowej stało się zawieszenie przez Brazylię członkostwa w UNASUL w kwietniu 2018 r. Problemy flagowej instytucji brazylijskiej wizji integracji odzwierciedlają w dużej mierze główne niedociągnięcia polityki regionalnej państwa, w tym jej krótkowzroczność, brak spójności, przedmiotowe traktowanie regionu w strategii globalnej państwa i nieufność państw południowoamerykańskich wobec ambicji Brazylii.

Administracja Jaira Bolsonaro (od 2018 r.), pomimo reorientacji głównych kierunków zaangażowania państwa na partnerów pozaregionalnych, nie może jednakże pozwolić sobie na utratę wpływów w najbliższym otoczeniu. Próbą przezwyciężenia impasu w stosunkach regionalnych stało się m.in. powołanie do życia w marcu 2019 r. Forum na rzecz Postępu i Rozwoju Ameryki Południowej (Fórum para o Progesso e Desenvolvimento da América do Sul, PROSUL). Nie ma ono już jednakże dynamiki UNASUL i jego rola w brazylijskiej polityce zagranicznej wiąże się raczej z uniknięciem marginalizacji, niż z kontynuacją roli przywódczej w regionie. Oznacza również w pewnym sensie odejście od regionalizmu 
traktowanego jako instrument polityki zagranicznej i oddanie inicjatywy pozostałych państwom.

Budowanie brazylijskiej strefy wpływów w oparciu o ideę wspólnoty południowoamerykańskiej pokazało, że spoiwo ideologiczne nie jest w stanie na dłuższą metę zrekompensować wielu lat marginalizacji regionu w polityce zagranicznej Brazylii. Ameryka Łacińska pozostanie jednakże dla niej istotnym punktem odniesienia, za czym przemawiają zarówno względy pragmatyczne, plasujące państwa latynoamerykańskie jako partnerów gospodarczych, niezbędnych dla podtrzymania rozwoju wewnętrznego, ale również polityczne, skłaniające do wzmocnienia integralności regionu w obliczu ekspansji Chin i przetasowań globalnych.

\section{Bibliografia}

S. Adins Venbiervliet, El liderazgo brasileño en Sudamérica: una aspiración de corta duración, «Revista Andina de Estudios Políticos» 2014, vol. IV, nr 2.

L. Bethell, Brazil and "Latin America”, «Journal of Latin American Studies», August 2010, vol. $42, \mathrm{nr} 3$.

J. Briceño-Ruiz, Rivarola Puntigliano A., Brazil and Latin America. Between the Separation and Integration Paths, Rowman\&Littlefield, Lexington Books, Lanham 2017.

S.W.Burges, Consensual hegemony: theorizing Brazilian foreign policy after the Cold War, «International Relations» 2008, vol. 22, nr 1.

K. Ekström, L.M. Alles, Brazilian Foreign Policy under Lula: from Non-Intervention to NonIndifference, «Political Perspectives» 2012, vol. 6, nr 2.

G.L. Gardini, Brazil: what rise of what power?, «Bulletin of Latin American Research» 2015, vol. $35, \mathrm{nr} 1$.

M. Gomes Saraiva, P.A. Velasco Júnior, A política externa brasileira e o "fim de ciclo" na América do Sul: Para onde vamos?, «Pensamiento Propio» julio-diciembre 2016, $\mathrm{nr} 44$.

A. Hurrell, Lula's Brazil:a rising power, but going where?, «Current History» 2008, vol. 107, nr 706.

K.E. Lehmann, Can Brazil lead? The breakdown of Brazilian foreign policy and what it means for the region, «Rising Powers Quaterly» 2017, vol. 2, nr 2.

A. Malamud, A leader without followers? The growing divergence between the regional and global performance of Brazilian foreign policy, «Latin American Politics and Society» 2011, vol. $53, \mathrm{nr} 3$.

C.G. Poggio Teixeira, Brazil and the institutionalization of South America: from hemispheric estrangement to cooperative hegemony, «Revista Brasileira de Política Internacional» 2011, vol. $54, \mathrm{nr} 2$.

L.L. Schenoni, The Brazilian rise and the elusive South American balance, „GIGA Research Programme: power, norms and governance in international relations Working Paper”, March 2015, nr 269 https://www.giga-hamburg.de/en/system/files/publications/ wp269_schenoni.pdf.

B. Sorj, S. Fausto, El papel de Brasil en América del Sur: estrategias y percepciones mutuas, [w:] B. Sorj, S. Fausto (red.), Brasil y América del Sur: miradas cruzadas, Buenos Aires 2011. 
J. Spyra, Mocarstwowe aspiracje Brazylii w kontekście regionalnym, [w:] M.F. Gawrycki (red.), Brazylia jako mocarstwo wschodzqce, Warszawa 2013.

A.G. Valladão, Emergent Brazil and the curse of the "hen'sflight”, [w:] M. Emerson, R. Flores (red.), Enhancing the Brazil-EU strategic partnership: from the bilateral to the global, Brussels 2013.

G. Villafañe, L.C. Santos, A América do Sul no discurso diplomático brasileiro, «Revista Brasileira de Política Internacional» julhio-dezembro 2005, vol. 48, nr 2.

F.Zanini, Foreign policy in Brazil: a neglected debate, «Harvard International Review» October 2014. 